\title{
Computer Assisted Radiology - 27th International Congress and Exhibition
}

Chairman: Stanley Baum, MD(USA), Co-Chair: Hans-Peter Meinzer, $P h D(D)$ 